\title{
„Mieszkańcy Sodomy byli źli...” (Rdz 13,13). Na czym polegał występek mieszkańców Sodomy?
}

\author{
"The people of Sodom were wicked" (Gen 13:13) \\ What Was the Transgression of the Inhabitants of Sodom?
}

\author{
KRZYSZTOF NAPORA \\ Katolicki Uniwersytet Lubelski Jana Pawła II \\ krzysztof.napora@kul.pl, ORCID: 0000-0002-7923-4517
}

\begin{abstract}
Streszczenie: W artykule autor porusza zagadnienie występku mieszkańców Sodomy w Rdz 19. Koncentrując uwagę na Rdz 19,1-11, wskazuje na kompleksowy charakter biblijnego obrazu grzesznego miasta. Wśród głównych rysów tego obrazu na pierwszy plan wysuwają się motywy grzesznych relacji o charakterze seksualnym (w tym również homoseksualnym), przemocy i gwałtu, a także motyw pogwałcenia prawa gościnności.
\end{abstract}

Słowa kluczowe: Księga Rodzaju, Rdz 19, Sodoma, gościnność, przemoc, akt homoseksualny, grzech Sodomy/sodomski, gwałt

Abstract: The article deals with the issue of the transgression(s) of the inhabitants of Sodom in Genesis 19. While focusing his attention on Genesis 19:1-11, the author points out the complex character of the biblical portrait of the sinful city. Among the main features of this picture, the motifs of sinful sexual relations (including homosexual acts), violence and rape, as well as the motif of the violation of the law of hospitality come to the fore.

Keywords: Genesis, Gen 19, Sodom, hospitality, violence, homosexual intercourse, Sodom's sin, rape

Prawdopodobnie niewiele tekstów biblijnych cieszy się dziś takim zainteresowaniem, prowokuje tak zaciekłe dyskusje i wywołuje tak głębokie kontrowersje, jak opowiadanie o zniszczeniu Sodomy zawarte w Rdz 19. Powodem rozbieżności okazuje się być w mniejszym stopniu historyczność opowiadania, skala spowodowanych Bożą interwencją zniszczeń czy też tożsamość podróżnych, których przybycie do Sodomy staje się katalizatorem łańcucha tragicznych wydarzeń. Co ciekawe, w centrum toczonych sporów wydaje się stać interpretacja istoty i natury występku (czy też występków), których dopuścili się (lub tylko pragnęli się dopuścić) mieszkańcy Sodomy.

To nadzwyczajne skupienie uwagi na pobocznym (jak by się wydawało) wątku opowiadania biblijnego, świadczy nie tyle o jakiejś niezwykłej erupcji zainteresowań studiami biblijnymi, ale raczej o temperaturze sporów toczonych współcześnie tam, gdzie stykają się płaszczyzny: religijna, filozoficzna, polityczna i światopoglądowa. 
Świadczyć może również o pewnym zamieszaniu, a nawet zagubieniu dotykającym współczesnego człowieka, szukającego prawdy o sobie samym („Adamie, gdzie jesteś?" - por. Rdz 3,9).

Niniejszy artykuł jest próbą konstruktywnego włączenia się w toczącą się dziś dyskusję i poszukiwania na kartach Biblii elementów prawdy o człowieku. Nasza refleksja na temat występków mieszkańców Sodomy rozwijać się będzie w trzech etapach. W pierwszej części motyw Sodomy i grzechu jej mieszkańców zostanie ukazany w kontekście Księgi Rodzaju i specyficznie Rdz 19. W drugiej części, na podstawie tekstu Rdz 19, zaprezentowane zostaną hipotezy dotyczące istoty występku mieszkańców Sodomy. W części trzeciej naszą uwagę skupimy na recepcji motywu Sodomy i jej występków w literaturze biblijnej i żydowskiej literaturze pozabiblijnej. Całości dopełni próba syntetycznego zebrania głównych wniosków przeprowadzonych badań.

\section{Sodoma i grzech jej mieszkańców w kontekście Księgi Rodzaju}

Nazwa Sodomy pojawia się 39 razy na kartach Biblii Hebrajskiej, z czego aż 20 razy w Księdze Rodzajuํ. Po raz pierwszy wspomniana jest w Rdz 10,19: „Granica Kananejczyków biegła od Sydonu w kierunku Geraru aż do Gazy, a potem w kierunku Sodomy, Gomory, Admy i Seboim - aż do Leszy"2. Wzmianka ta, stanowiąc na pozór jedynie fragment opisu geograficznej dystrybucji potomków Noego, wydaje się być jednocześnie elementem negatywnego obrazu Sodomy, który niemal od początku kreśli redaktor biblijny. Należy zauważyć, że według zawartego w Rdz 10 opisu, Sodoma - regularnie wymieniana na kartach Biblii wraz z Gomorą (19 razy!) - stanowi dziedzictwo Kanaana, wnuka Noego, zrodzonego z Chama (Rdz 9,18). To właśnie Kanaan jako pierwszy ponosi konsekwencję występku swego ojca, Chama: zostaje przeklęty przez Noego i określony „najniższym sługą swych braci” (zob. Rdz 9,25-27). Imiona potomków Kanaana, które wymienia Rdz 10,15-18, przywodzą na myśl nazwy narodów, które pokona Izrael wkraczając do Ziemi Obiecanej.

Wspominając Sodomę w Rdz 14, redaktor biblijny ucieka się do pewnej ironii W kontekście konfrontacji w dolinie Siddim pomiędzy koalicją pięciu królów, a wojskami czterech królów pod wodzą Kedorlaomera elementem tej ironii wydaje się być fakt klęski koalicji liczniejszej, który może świadczyć o nieprzygotowaniu i pochopnej decyzji o buncie przeciw Kedorlaomerowi. Ponadto spośród pięciu królów ucie-

1 Oprócz Księgi Rodzaju nazwa „Sodoma” pojawia się również w księgach: Ezechiela (6), Izajasza (4), Jeremiasza (3), Powtórzonego Prawa (2), Lamentacji (1), Amosa (1) i Sofoniasza (1)

2 Cytaty biblijne użyte w artykule (o ile nie zaznaczono inaczej) zaczerpnięte zostały z 5 wydania Biblii Tysiąclecia.

3 Zob. Himbaza - Schenker - Edart, Question of Homosexuality, 6. 
kających w obliczu klęski, to właśnie król Sodomy Bera i król Gomory Birsza skryli się, czy raczej wpadli do dołów, z których wydobywano smołę i w ten sposób dostali się do niewoli. Tekst biblijny wyraźnie wspomina tylko Sodomę i Gomorę jako miasto złupione przez najeźdźców. Ironicznie pobrzmiewa wzmianka o siłach Abrahama, który śpieszy na pomoc uprowadzonemu do niewoli bratankowi na czele trzystu osiemdziesięciu ludzi i jest w stanie pokonać siły, którym nie były w stanie stawić czoła połączone wojska pięciu królów. Całości ironicznego obrazu Sodomy dopełnia fakt, że Abraham odmawia przyjęcia daru wdzięczności za ocalenie od króla Sodomy: „żebyś potem nie mówił: To ja wzbogaciłem Abrama” (Rdz 14,23).

Według Rdz 13,10-12 Dolina Jordanu aż po Soar (wraz z Sodomą i Gomorą) ze względu na swoje walory (okolica ta była ,jak ogród Pana, jak ziemia egipska”) stanie się przedmiotem wyboru Lota, gdy ten oddzieli się od Abrama i zamieszka w tej okolicy „rozbiwszy swe namioty aż po Sodomę”". Mimo to redaktor biblijny nie omieszka wspomnieć, że kres niezwykłej „urodzie” ziemi położy Pan, niszcząc Sodomę i Gomorę $(13,10)$. Zniszczenie to wydaje się naturalną konsekwencją moralnej kondycji mieszkańców Sodomy, o których w Rdz 13,13 redaktor biblijny powie, że „byli źli” i „dopuszczali się ciężkich przewinień (dosł. „grzeszyli bardzo”) wobec Pana". Zarówno wzmianka o występkach mieszkańców Sodomy, jak i zniszczeniu obu miast wydaje się stanowić zapowiedź opowiadania w Rdz 18-19, które stanowić będzie apogeum negatywnego opisu Sodomy. Obraz zniszczenia miasta, który czytelnik Księgi Rodzaju ogląda oczyma Abrahama w Rdz 19,28, stanowi jednocześnie ostatnią wzmiankę na temat Sodomy w tej księdze: znika ona z jej kart podobnie jak nagle zniknęła z powierzchni ziemi.

Można odnieść wrażenie, że redaktor Księgi Rodzaju przygotowuje opowiadanie o Sodomie, którego centralną część stanowić będzie Rdz 19 poprzez elementy, które od samego początku ukazują miasto i jego mieszkańców w negatywnym świetle. Wiersz Rdz 13,13 wspomina wyraźnie, iż mieszkańcy Sodomy (אנשי סדם (אדים) „grzeszyli bardzo przeciw Panu” (רעים וחטאים ליהוה מאד, dosł. „źli i bardzo grzeszni wobec Pana”). Wzmianka o „bardzo ciężkich” (כבדה מאד לפד מדיהד) występkach mieszkańców Sodomy powróci w Rdz 18,20 jako bezpośrednie preludium do opisu wydarzeń, które rozegrają się w Sodomie w Rdz 19. Ich ciężar gatunkowy wydaje się podkreślony przez fakt, że Pan decyduje się na osobistą interwencję, przypominającą do złudzenia Jego zaangażowanie w opowiadaniu o wieży Babel (Rdz 11,1-9): „Głośno się rozlega skarga na Sodomę i Gomorę, bo występki ich mieszkańców są bardzo ciężkie. Chcę więc zstąpić i zobaczyć, czy postępują tak, jak głosi oskarżenie, które do Mnie doszło, czy nie; dowiem się" (Rdz 18,20-21). Pomimo tak mocnych stwierdzeń, redaktor biblijny nie informuje czytelnika na temat szczegółów grzesznego postępowania mieszkańców Sodomy. Powściągliwość w tym względzie zachowuje zarówno Pan, który informuje Abrama o swoich planach, jak i sam patriarcha, który

Rdz 14,12 informuje, że Lot był mieszkańcem Sodomy. 
przystępuje do targu z Panem, pomijając zupełnie szczegóły dotyczące postępowania mieszkańców Sodomy. Być może jest to element strategii narracyjnej redaktora Księgi Rodzaju, który zaprasza w ten sposób swego słuchacza, czy też czytelnika, by w pewnym sensie razem z Bogiem „zszedł do Sodomy”, aby przekonać się o prawdziwości oskarżeń kierowanych przeciw miastu. Zniszczenie Sodomy, opisane w Rdz 19, stanowi jednoznaczny dowód, że skrutynium dokonane przez wysłańców Boga wykazało, iż oskarżenia okazały się prawdziwe. A zatem, aby poznać istotę grzechu mieszkańców Sodomy słusznym wydaje się przede wszystkim zwrócić uwagę na opis wydarzeń, które dokonały się w Sodomie w kontekście wizyty Bożych wysłańców (Rdz 19,1-29).

Naprzeciw wchodzącym wieczorem do Sodomy wysłańcom Boga wychodzi Lot, który o tej porze siedzi w bramie miasta. Szczegół ten wydaje się podkreślać z jednej strony zmianę, która dokonała się w życiu bratanka Abrahama. Z człowieka, który prowadząc koczowniczy tryb życia, wędrował ze swymi stadami, stał się on obywatelem miasta, mającym swój stały dom. Fakt przebywania Lota w bramie miasta - miejscu, gdzie zasiadali ci, którzy sprawowali władzę nad miastem lub cieszyli się poważaniem wśród jego mieszkańców - mógłby wskazywać na pewien stopień integracji Lota oraz świadczyć o jego pozycji w lokalnej społeczności ${ }^{5}$. Dalsze wydarzenia (zwłaszcza Rdz 19,9) ukażą jednak jasno, że zarówno pozycja ta, jak i ewentualna integracja Lota zbudowane były na bardzo nietrwałych podstawach. W Rdz 19,1-3 Lot, mimo iż sam był przybyszem w Sodomie (a może właśnie dlatego!), w pewnym sensie samotnie reprezentuje miasto, okazując gościnność przybyszom: oddaje im pokłon i zaprasza, aby zechcieli odpocząć, spędzając noc w jego domu. Gościnność Lota zostaje dodatkowo podkreślona poprzez wzmiankę o nacisku, jaki wywiera na posłańców (פצר), którzy początkowo odmawiają przyjęcia gościny, decydując się spędzić noc na zewnątrz. Zdaniem niektórych egzegetów, naleganie Lota może być pierwszym delikatnym sygnałem dotyczącym potencjalnego niebezpieczeństwa, jakie mogłoby grozić wysłańcom spędzającym noc w przestrzeni publicznej Sodomy ${ }^{6}$.

Wersety Rdz 19,4-11 wdają się kluczowe w określeniu natury występków mieszkańców Sodomy. Gościnność Lota (przypominająca nieco postawę Abrahama

5 Zob. Matthews, „Hospitality”, 4; Lemański, Księga Rodzaju, 372. Na integrację tę wydaje się wskazywać wzmianka w Rdz 19,14 o potencjalnych zięciach. Komentarze rabiniczne sugerują, że pełnił w Sodomie funkcję sędziego (zob. Hershon, A Rabbinical Commentary, 106) lub nawet najwyższego sędziego (Gen. R. 50.3). Zob. Lyons, Canon, 215. Nie brak jednak również komentarzy, które zwracają uwagę na fakt, że Lot przebywa w bramie samotnie, co może sugerować jego izolację w lokalnej społeczności. Zob. Wenham, Genesis 16-50, 54.

6 Wenham, Genesis 16-50. Jak zauważa Scott Morschauser („Hospitality”, 469), naleganie, by przybysze spędzili noc w domu Lota może również sugerować chęć sprawowania przez Lota kontroli nad nieznanymi podróżnymi. 
z Rdz 18$)^{7}$, zostaje w nich radykalnie skontrastowana z postawą mężczyzn zamieszkujących Sodomę. Otaczają oni dom Lota, w którym znaleźli schronienie przybysze, i żądają wyprowadzenia ich na zewnątrz. Co ciekawe, redaktor Księgi Rodzaju dwukrotnie w wersecie 4 używa rzeczownika איש w איש w formie liczby mnogiej (אנשי אושי סדם ,mężczyźni miasta”czyźni Sodomy”), przez co nie tylko nawiązuje do określenia mieszkańców z Rdz 13,13 (אנשי סדם), ale wydaje się również sugerować, że chodzi o męską część społeczności Sodomy. Z kolei użycie meryzmu: „młodzi i starzy” (מנער ועד־זן, dosł. „od chłopca, aż po starca”) oraz wyrażenia „cały lud z [wszystkich] krańców [miasta]" (כל־העם מקצה) wskazywać mogą pokoleniowy i powszechny charakter czynu, którego pragną się dopuścić mężczyźni Sodomy. Ich pragnienie zostaje skonkretyzowane w pytaniu oraz żądaniu, które adresują do Lota w Rdz 19,5: „Gdzie tu są ci ludzie, którzy przyszli do ciebie tego wieczoru? Wyprowadź ich do nas, abyśmy mogli z nimi obcować!”. Choć wcześniej nieobecni w bramie miasta, mężczyźni Sodomy okazują się jednak doskonale poinformowani na temat wysłańców, czasu ich przybycia do miasta oraz miejsca ich postoju. W tym kontekście pytanie: „Gdzie są ludzie, którzy przyszli do ciebie tego wieczoru?” wydaje się pytaniem retorycznym, choć element poznania nabiera w tej scenie szczególnego znaczenia za sprawą żądania, które formułują otaczający dom Lota mężczyźni. Brzmi ono dosłownie: „wyprowadź ich do nas, abyśmy ich poznali (ונדעה אתם)". Sformułowanie to wydaje się tworzyć nieco ironiczny kontrast w stosunku do Rdz 18,21, gdzie Pan wyraża chęć zejścia do Sodomy, aby „poznać” prawdę o jej mieszkańcach. Charakter owego „poznania”, którego pragną mieszkańcy Sodomy - wyrażonego hebrajskim czasownikiem ידע - stał się jednym z punktów spornych w dyskusjach toczonych wokół zagadnienia istoty grzechu mieszkańców Sodomy.

W obliczu żądania, które przedstawiają mężczyźni Sodomy, Lot, wychodząc do nich na zewnątrz domu, odpowiada najpierw apelem: „Bracia moi, proszę was, nie dopuszczajcie się tego występku!” (Rdz 19,7). Ponieważ, jak się wydaje, nie odnosi on skutku, Lot składa szokującą (przynajmniej według naszych standardów) propozycję: „Mam dwie córki, które jeszcze nie żyły z mężczyzną [dosł. „nie poznały mężczyzny"], pozwólcie, że je wyprowadzę do was; postąpicie z nimi, jak się wam podoba, bylebyście tym ludziom niczego nie czynili, bo przecież są oni pod moim dachem!" $(19,8)$. W zdaniu tym, po raz drugi w tym opowiadaniu pojawia się hebrajski czasownik ידע. Tym razem jednak, bez cienia wątpliwości, wskazuje on na relację o charakterze seksualnym. Propozycja Lota spotyka się z gwałtowną reakcją zgromadzonych wokół domu mężczyzn Sodomy. Nie tylko odrzucają oni ofertę Lota, ale również posuwają się do agresji słownej, przypominając jego niższy status społeczny jako przybysza, oraz gróźb, po których następują konkretne czyny skierowane przeciw Lotowi i wysłannikom, którzy zatrzymali się pod jego dachem: „I rzucili

7 Szerzej na temat porównania postaci Abrahama i Lota oraz gościny przez nich udzielonej zob. Lyons, Canon, 218-225. 
się gwałtownie na tego męża, na Lota, inni zaś przybliżyli się, aby wyważyć drzwi” $(19,9)$. Bezpośrednie zagrożenie Lota oraz ludzi zgromadzonych w jego domu staje się impulsem do podjęcia działania przez wysłańców Boga. Najpierw pomagają oni Lotowi bezpiecznie schronić się za zaryglowanymi drzwiami domu, a następnie, jak czytamy w Rdz 19,11: „mężczyzn u drzwi domu, młodych i starych, porazili ślepotą, tak że próżno usiłowali oni odnaleźć wejście”8. Interwencja Bożych wysłańców wydaje się jednoznacznie wskazywać, że cel ich przybycia do Sodomy został osiągnięty: skrutynium potwierdziło prawdziwość zarzutów podnoszonych przeciw Sodomie. Kolejne wersety rozdziału 19 przynoszą opis Bożej interwencji skierowanej przeciw grzesznemu miastu i gwarantującej jednocześnie ocalenie Lota i jego bliskich. Jak wspomnieliśmy wyżej, wersety Rdz 19,4-11 wydają się skrywać klucz do zrozumienia, na czym w istocie polegał występek mieszkańców Sodomy. Egzegeci wskazują zazwyczaj na trzy elementy, które stanowić mogą rozwiązanie tej zagadki i które jednocześnie różnicują niekiedy opinie badaczy. To one staną się przedmiotem naszej analizy w dalszej części pracy.

\section{Istota występku Sodomy - trzy hipotezy czy potrójna hipoteza?}

Pierwszym, zasygnalizowanym już wcześniej elementem jest czasownik ידע, „Znać”, „poznać” w Rdz 19,59. Użyty przez mężczyzn Sodomy w żądaniu skierowanym do Lota, określać miał ich zamiary w stosunku do Bożych wysłańców. „Wyprowadź ich do nas, abyśmy mogli z nimi obcować" - czytamy w Biblii Tysiąclecia, będącej odbiciem tradycyjnego nurtu egzegezy, która przyjmuje, że czasownik ידע w Rdz 19,5 wyraża sens „obcowania cielesnego" ${ }^{10}$. Warto nadmienić, że dziś takie stanowisko bywa określane jako konserwatywne, a jego zwolennicy nazywani Chrześcijańską Prawicą ${ }^{11}$. Jego przeciwnicy zwracają uwagę przede wszystkim na fakt, że na blisko 950 wystąpień czasownika ידע w Biblii Hebrajskiej, jedynie 15 razy wskazuje on jednoznacznie na "poznanie" mające charakter relacji seksualnej ${ }^{12}$. Sugerują oni, że użyty w Rdz 19,5 ידע oznacza, że mężczyźni Sodomy chcieli poznać tożsamość przybyłych lub też zapoznać się z przybyszami, których Lot w pewnym sensie zawłaszczył

8 Trudno nie dostrzec w tym kolejnego elementu ironii: ci, którzy żądali „poznania” przybyszów, teraz dotknięci ślepotą, nie są w stanie nie tylko ich „poznać”, ale nawet odnaleźć wejścia do domu.

9 Słowo to ma szerokie pole semantyczne. Może również oznaczać „karać”, „poniżyć”, „być uległym”, „być cichym".

10 Zob. Skinner, Genesis, 307; Wright, „Homosexuality”, 292; Wenham, „Attitude to Homosexuality”, 361; C. Westermann, Genesis 12-36, 301.

11 Zob. Toensing, „Women of Sodom”, 62.

12 Zob. Rdz 4,1.17.25; 19,8; 24,16; 38,26; Lb 31,17.18.35; Sdz 11,39; 19,25; 21,11.12; 1 Sm 1,19; 1 Krl 1,4. 
przez swoją gościnę $e^{13}$. Scott Morschauser sugeruje, że werset 5 i pragnienie mężczyzn Sodomy, by poznać przybyłych, stają się zrozumiałe w kontekście praktyki potwierdzonej zarówno w tekstach biblijnych (choćby historia Józefa i jego braci przybyłych do Egiptu po żywność), jak i w źródłach pozabiblijnych. Praktyka ta, dotycząca przybyszów szukających schronienia w danej społeczności, wskazywała na konieczność przeprowadzenia swego rodzaju dochodzenia, mającego ujawnić tożsamość i zamiary szukających azylu ${ }^{14}$. Morschauser sugeruje, że czasownik ידע w 19,5 może być również elementem terminologii prawnej, wskazującym na procedurę oficjalnego przesłuchania, mającego potwierdzić, że przybyli do Lota wieczorową porą ludzie nie mają złych zamiarów i nie stanowią zagrożenia dla bezpieczeństwa mieszkańców Sodomy. W starożytności procedura taka mogła się wiązać z użyciem wszelkich dostępnych środków przymusu - również tych najbardziej brutalnych - celem uzyskania od przybyszów potrzebnych informacji. Zdaniem Morschausera, to właśnie obawa dotycząca ewentualnej brutalności procedury przesłuchania mogła skłonić Lota do podjęcia kroków mających ochronić gości, którym udzielił schronienia ${ }^{15}$. Żądanie mieszkańców Sodomy można jednocześnie odczytać jako zakwestionowanie decyzji Lota, który zasiadając w bramie, wpuścił przybyszów do miasta. Odmowa ich wydania ze strony Lota mogłaby z kolei być odczytana jako nielojalność w stosunku do mieszkańców ze strony człowieka, który sam miał status przybysza.

Można wskazać szereg trudności, które rodzą się w kontekście przytoczonych tu „nie-tradycyjnych” (często „nie-konserwatywnych" i „nie-prawicowych”) prób wyjaśnienia kwestii „poznania”, którego chęć wyrażają mężczyźni Sodomy w Rdz 19,5. Po pierwsze, jak się wydaje, o znaczeniu poszczególnych terminów decyduje nie tyle statystyka - rzadkość występowania danych słów czy znaczeń - ale bezpośredni kontekst ich użycia ${ }^{16}$. W przypadku terminu ידע w Rdz 19,5 zwraca uwagę fakt, że redaktor biblijny używa tego czasownika również w wierszu 8, gdzie - jak wspomnieliśmy - wskazuje on jednoznacznie na relację o charakterze seksualnym. Dalej, jeśli czasownik ידע w wersecie 5 miałby oznaczać jedynie chęć poznania tożsamości przybyłych, niezrozumiała wydaje się propozycja Lota, który pragnie wydać w ręce otaczających jego dom dwie swoje córki. Nawet jeśli potraktowalibyśmy jego propozycję jako rodzaj gwarancji bezpieczeństwa oferowanej mieszkańcom Sodomy, w której córki pełniłyby rolę zakładniczek, to niezrozumiałe wydaje się podkreślenie faktu ich dziewictwa („nie znały mężczyzny”) wraz ze wskazaniem, że mężczyźni mogą z nimi uczynić wszystko, „co słuszne jest w ich oczach”. Jeśli żądanie poddania przybyłych przesłuchaniu było zwyczajną procedurą prawną, to jak zrozumieć apel Lota: „Bracia moi, proszę was, nie dopuszczajcie się tego występku!”, który sugeruje

\footnotetext{
Zob. Bailey, Homosexuality, 3-4; McNeill, The Church, 54-55.

Zob. Morschauser, „Hospitality”, 470-471.

Zob. Morschauser, „Hospitality”, 472.

Zob. Grisanti, „Homosexuality”, 120.
} 
jednoznacznie negatywną ocenę tego żądania? Wreszcie na kontekst seksualny żądania mężów Sodomy wydaje się wskazywać paralelne opowiadanie w Sdz 19, gdzie czasownik ידע, został użyty jednoznacznie w sensie obcowania cielesnego - również w znaczeniu aktu homoseksualnego ${ }^{17}$.

Przytoczone wyżej argumenty wydają się jednoznacznie wskazywać, że zamiar mężczyzn Sodomy w stosunku do wysłanników Boga wyrażony w Rdz 19,5 dotyczy sfery seksualnej ${ }^{18}$, a czasownik ידע użyty jest w znaczeniu aktu cielesnego o charakterze homoseksualnym, w którym zarówno podmiotem aktu, jak i jego przedmiotem są mężczyźni. Spostrzeżenie to w połączeniu z informacją z wersetu 4, dotyczącą powszechnego i międzypokoleniowego charakteru zgromadzenia mężczyzn wokół domu Lota, prowadzić może do wniosku, jakoby jedyną albo główną przyczyną zniszczenia Sodomy była homoseksualna skłonność męskiej części jej mieszkańców ${ }^{19}$. Stwierdzenie takie w naszym odczuciu nie wyraża jednak w pełni ministerium iniquitatis mieszkańców Sodomy i koncentruje uwagę tylko na jednym z elementów opowiadania w Rdz 19.

Aspektem, którego nie sposób pominąć szukając odpowiedzi na pytanie o naturę występku mieszkańców Sodomy jest oczywiście przemoc. Zwróciliśmy wcześniej uwagę na fakt, że odmowna odpowiedź Lota na żądanie otaczających jego dom mężów Sodomy prowokuje wybuch gniewu, który zwraca się przeciw samemu Lotowi oraz jego domowi. Agresja ta, jak widzieliśmy, ma nie tylko wymiar słowny, w którym przypomniany zostaje Lotowi niski status społeczny przybysza, ale również wymiar przemocy fizycznej, przed którą ocala Lota jedynie szybka interwencja jego gości. Szczególny jednak aspekt tej przemocy, która cechuje mężczyzn Sodomy, dotyczyć ma sfery seksualnej. Głównym ich występkiem miała być podjęta próba gwałtu. Zwolennicy poglądu, według którego to nie relacje homoseksualne jako takie, ale właśnie gwałt miałby stanowić istotę występku Sodomy, podkreślają często, że zło tego aktu w żaden sposób nie jest związane z preferencją seksualną sprawców ${ }^{20}$. Przywołują tu jako przykład paralelne opowiadanie w Księdze Sędziów, gdzie mieszkańcy Gibea nie osiągnąwszy celu, jakim był akt homoseksualny, zadawalają się gwałtem dokonanym na kobiecie. Ich zdaniem istoty problemu nie stanowi sam akt homoseksualny, ale jego niedobrowolność. Innymi słowy (ironizując nieco), gdyby wysłańcy Boga dobrowolnie pozwolili się „poznać”, Sodoma mogłaby do dziś być atrakcyjnym kurortem nad Morzem Martwym. W konsekwencji, jak zauważa Phyllis Bird, opowiadanie o Sodomie nie może być traktowane jako punkt odnie-

17 Rozmiar niniejszego opracowania nie pozwala szerzej rozwinąć tematu podobieństw i relacji między opowiadaniami w Rdz 19 i Sdz 19, które wydają się być ewidentne. Pewne elementy podobieństwa zostaną podkreślone w dalszej części artykułu.

18 Przyznają to również autorzy, którzy sądzą, iż główny problem nie dotyczy relacji homoseksualnych. Zob. Nissinen, Homoeroticism, 46.

19 Zob. Fields, „The Motif”, 28; Alter, „Sodom”, 248-254; por. Toensing, „Women of Sodom”, 61.

20 Zob. Gnuse, „Gay Texts”, 73. 
sienia w dzisiejszych dyskusjach na temat relacji homoseksualnych. Powodem, na który się przy tym powołuje jest właśnie owa „niedobrowolność" aktów homoseksualnych, charakteryzująca kulturę starożytnego Izraela. Jak zauważa: „the Israelite authors could only conceive of participation in male homoerotic acts as forced.... [A]ncient Israelites had no experience or conception of male homoerotic relations as consensual"21.

Pośród zwolenników tej hipotezy podkreśla się również niekiedy fakt, że gwałt, którego próbują dokonać mężczyźni Sodomy, nie jest wyrazem skłonności homoseksualnej, lecz rozumiany był raczej jako akt dominacji, mający na celu poniżenie i podporządkowanie sobie ofiary ${ }^{22}$. Akt ten skierowany mógł być zwłaszcza przeciw osobom o niższym statusie - w przypadku opowiadań w księgach Rodzaju i Sędziów przeciw obcym, przybyszom. Jak podkreśla Martti Nissinen, powołując się na George’a R. Edwardsa: „This is the background for understanding the Sodomite men's rape attempt. George R. Edwards got to the heart of the matter by defining the Sodomite's activity as phallic aggression generated by xenophobic arrogance" 23 .

W ten sposób docieramy do trzeciego elementu, który podkreślany bywa w kontekście dyskusji na temat występku mieszkańców Sodomy, mianowicie pogwałcenia prawa gościnności. Podsumowując swoje badania na temat motywu Sodomy i Gomory w tradycji biblijnej, Weston W. Fields zauważa, że odniesienie do „obcego w twoich bramach" jest głównym powracającym motywem opowiadań o Sodomie (Rdz 19), Gibea (Sdz 19-21) oraz Jerychu (Joz 6) ${ }^{24}$. Warto przy tym zwrócić uwagę, że w opowiadaniu w Rdz 19 w grę wchodzi nie tylko pogwałcenie prawa gościnności w stosunku do Bożych wysłańców, ale również w stosunku do Lota, będącego przybyszem w Sodomie. To jego honor zostaje w pierwszym rzędzie naruszony poprzez próbę brutalnego potraktowania przybyszów, którym Lot udzielił schronienia pod swoim dachem ${ }^{25}$.

Motyw gościnności wydaje się odgrywać istotną rolę w kontekście opowiadania o patriarchach. Wystarczy wspomnieć tylko gościnę Abrahama w Rdz 18. Ten właśnie aspekt bywa dziś mocno podkreślany w interpretacjach sceny w Rdz 19. W opisie występku z całą pewnością nie powinien być on pomijany, nawet jeśli z naszej perspektywy nie wydaje się on szczególnie istotny. Nie zapominajmy, czym było i czym jest święte prawo gościnności na Bliskim Wschodzie. Jego znaczenie z pew-

21 Bird, „OT Contributions”, 148.

22 Akt ten był stosowany niekiedy jako element poniżenia i oznaka dominacji w stosunku do pokonanych wrogów i jeńców. Zob. Wenham, „Attitude to Homosexuality”, 361.

23 Nissinen, Homoeroticism, 48; por. Edwards, Gay/Lesbian, 46.

24 Zob. Fields, Sodom and Gomorrah, 186.

25 Zob. Boyarin, „Are There Any Jews”, 349; Nissinen, Homoeroticism, 49. W tym kontekście rodzi się również pytanie, czy Lot, sam będąc przybyszem, miał prawo udzielać gościny w imieniu mieszkańców Sodomy. Zob. Matthews, „Hospitality”, 4. 
nością zostaje podkreślone przez fakt, że zarówno w opowiadaniu z Księgi Rodzaju, jak i Księgi Sędziów gospodarze gotowi są na poświęcenie członków własnej rodziny, aby uniknąć pogwałcenia $\mathrm{w}$ ich domu prawa gościnności.

Podkreślając wagę naruszenia prawa gościnności, James A. Loader zwraca uwagę, że wszystkie trzy wymienione wyżej elementy razem stanowią istotę grzechu mieszkańców Sodomy. Jak pisze:

Their sin is a three-in-one matter. They violate the sacred law of hospitality and in so doing give themselves over to depravity of a homosexual nature (cf Lv 18:22, 20:13). At the same time it must be said that the sin here is not just a private homosexual act, but homosexual mob rape. [...] It highlights the fact that sexual misdemeanour, even though it certainly is part of the sin of 'sodomy', is not the central or most important part. The Sodomites are engaging in an anti-social act of violence and oppression. It is not for nothing that this is expressed in the motif of perverse sex. This is not only to show that the Sodomites wanted to 'humiliate and "demasculinize" the guests' (as Shafer 1984:773 calls it). The Sodomites make natural intercourse impossible by violating the social fibre of the community as represented by the motif of hospitality. They pervert the natural obligations by which life in ancient communities was made possible ${ }^{26}$.

Jak się wydaje, żaden z trzech elementów osobno, ale wszystkie trzy razem ${ }^{27}$ tworzą dopiero całościowy obraz nieprawości mieszkańców Sodomy, która w ten sposób stanie się symbolem i modelem grzesznej społeczności. W następnej części spróbujemy zwrócić uwagę na recepcję tego modelu w księgach biblijnych i wybranej literaturze pozabiblijnej.

\section{Motyw Sodomy i jej występków w księgach biblijnych i żydowskiej literaturze pozabiblijnej}

Sodoma i Gomora, których występki i zagłada opisane zostały na kartach Księgi Rodzaju, stają się w Biblii symbolem i punktem odniesienia dla autorów biblijnych. Pragnąc wstrząsnąć słuchaczy wizją występku, porównują go oni do grzechu mieszkańców Sodomy i Gomory. Roztaczając wizję potencjalnej kary, ukazują ją w odniesieniu do zniszczenia, które spotkało Sodomę. Co ciekawe, w niektórych tekstach,

26 Loader, Two Cities, 37.

27 Zob. Gagnon, The Bible, 75-76, 78. Robert A.J. Gagnon wspomina również możliwy czwarty element obrazu nieprawości mieszkańców Sodomy, jakim jest próba seksualnej relacji między ludźmi a należącymi do sfery boskiej posłańcami Bożymi. Próba ta, podjęta przez mieszkańców Sodomy, wpisywałaby opowiadanie o zniszczeniu Sodomy w obecny na kartach Biblii ciąg opowiadań, w których pojawia się motyw naruszenia granicy dzielącej świat Boski i świat ludzki (zob. Rdz 3; 6,1-4; 11,1-9). 
tak Starego, jak i Nowego Testamentu, oprócz zwykłego porównania dotyczącego stopnia zepsucia czy też miary popełnionych występków, pojawiają się również odniesienia do konkretnych grzechów lub - szerzej - postaw mieszkańców Sodomy.

Prorok Izajasz przywołuje przykład Sodomy wskazując na jawność czy też oczywistość złego postępowania chylących się ku upadkowi Jerozolimy i Judy: „Stronniczość ich świadczy przeciw nim, jak Sodoma rozgłaszają swój grzech, nie ukrywają go. Biada im, bo sami sobie gotują nieszczęście” $(3,9)$. Prorok Jeremiasz używa motywu grzesznych miast Sodomy i Gomory, piętnując grzechy duchowej elity mieszkańców Jerozolimy: „A wśród proroków Jerozolimy widziałem obrzydliwość: cudzołóstwo, zatwardziałość w kłamstwie i popieranie złoczyńców, przy czym nikt się nie nawraca ze swej niegodziwości. Stali się oni wszyscy dla Mnie jakby Sodomą, a mieszkańcy ich jakby Gomorą” $(23,14)$. Choć prorok precyzyjnie określa „obrzydliwość”, której dopuszczają się współcześni mu prorocy („cudzołóstwo, zatwardziałość w kłamstwie i popieranie złoczyńców”), odniesienie do Sodomy i Gomory dotyczy, jak się wydaje, przede wszystkim nagromadzenia występków oraz braku jakiejkolwiek chęci nawrócenia („nikt się nie nawraca ze swej niegodziwości”). Ta kumulacja zła oraz niechęć do nawrócenia stają się niekiedy dla autorów biblijnych podstawą nie tylko do porównania z grzesznymi miastami, ale i do określenia dopuszczających się występku mianem mieszkańców Sodomy i Gomory: „Słuchajcie słowa Pańskiego, wodzowie sodomscy, daj posłuch prawu naszego Boga, ludu Gomory!” (Iz 1,10).

Zwolennicy „nie-tradycyjnych” hipotez na temat istoty występku mieszkańców Sodomy powołują się często na Księgę Ezechiela. W rozdziale 16 prorok, kierując swe napomnienie do Jerozolimy, wskazuje na jej duchowe czy też moralne pokrewieństwo z Sodomą. Wyraźnie przy tym podkreśla istotę złego postępowania Sodomy: „Oto taka była wina siostry twojej, Sodomy: ona i jej córki odznaczały się wyniosłością, zachłannością i spokojną beztroską, ale nie wspierały biednego i nieszczęśliwego, co więcej, uniosły się pychą i dopuszczały się tego, co wobec Mnie jest obrzydliwością. Dlatego je odrzuciłem, jak to widziałaś" (Ez 16,49-50). Wykaz występków wydaje się wskazywać na szeroko pojęty "grzech społeczny” Sodomy, które apogeum stanowić miałby brak troski o „biednych i nieszczęśliwych”. I choć w zakończeniu listy pojawia się również wzmianka o „obrzydliwości” (תועבה), którym to terminem w regulacjach zawartych w Kpł 18,22 i 20,13 określa się relacje seksualne między mężczyznami, to jednak zwolennicy interpretacji występków Sodomy w kategoriach grzechu społecznego widzą w nim jedynie rodzaj zbiorczego określenia dla wymienionych wcześniej występków: pychy, zachłanności, beztroski i niesprawiedliwości społecznej. Komentując tę interpretację, Robert A.J. Gagnon zwraca uwagę, że prorok przedstawia podobny wykaz występków w 18,10-13. Lista ta kończy się określeniem: „wszystkie te bezeceństwa” (כל־התועבות האלה). W tym jednak przypadku rzeczownik התועבות („obrzydliwości”, „bezeceństwa”) występuje w formie liczby mnogiej. Jednocześnie w wykazie występków ten sam rzeczownik pojawia się w formie liczby pojedynczej (תועבה - Ez 18,12), wskazując na grzech - różny od 
tzw. grzechów społecznych (np. ucisku ubogiego i potrzebującego, zatrzymania zastawu) - o którym mowa w Kpł 18; 20. Co ciekawe, jak zauważa Gagnon, w Kpł 18 rzeczownik תועבה również występuje na przemian w liczbie pojedynczej i mnogiej, przy czym forma liczby pojedynczej wydaje się tu wskazywać konkretnie na akty homoseksualne ${ }^{28}$.

Autor Księgi Mądrości, choć nie wspomina wprost nazwy Sodoma, czyni aluzję do opowiadania w Rdz 19, wspominając grzech mieszkańców Egiptu. W jego interpretacji istotę występku wydaje się stanowić naruszenie prawa gościnności: „A i kary przychodziły na grzeszników nie bez uprzednich znaków - gwałtownych piorunów. Słusznie cierpieli za swe własne złości, bo żywili ku gościom najgorszą nienawiść. Tamci nie przyjęli przybyszów nieznanych, ci wzięli w niewolę dobroczynnych gości" (Mdr 19,13-14). Podobną aluzję do występków Sodomy (bez wyraźnego wskazania nazwy miasta) autorzy odnajdują również w Syr 10,12-18. Tym razem jednak istotę występku wydaje się stanowić niesprawiedliwość społeczna.

Motyw pogwałcenia prawa gościnności pojawia się w nowotestamentowych nawiązaniach do Sodomy. Posyłając apostołów na misję głoszenia królestwa Bożego Jezus wspomina konsekwencje, jakie poniosą miasta, które nie przyjmą posłańców i odrzucą ich nauczanie: „A jeśliby was gdzieś nie chciano przyjąć i nie dano posłuchu słowom waszym, wychodząc z takiego domu albo miasta, strząśnijcie proch z nóg waszych! Zaprawdę, powiadam wam: Ziemi sodomskiej i gomorejskiej lżej będzie w dzień sądu niż temu miastu” (Mt 10,14-15; por. Łk 10,10-12). Według słów Jezusa los podobny do losu Sodomy czeka również miasto, którego mieszkańcy - na wzór mieszkańców Sodomy - odrzucili wezwanie do nawrócenia: „A ty, Kafarnaum, czy aż do nieba masz być wyniesione? Aż do Otchłani zejdziesz. Bo gdyby w Sodomie działy się cuda, które się w tobie dokonały, przetrwałaby aż do dnia dzisiejszego. Toteż powiadam wam: Ziemi sodomskiej lżej będzie w dzień sądu niż tobie" (Mt 11,23-24).

Na seksualną interpretację występku mieszkańców Sodomy wydaje się z kolei wskazywać autor Listu św. Judy: „Jak Sodoma i Gomora, i okoliczne miasta - w po-

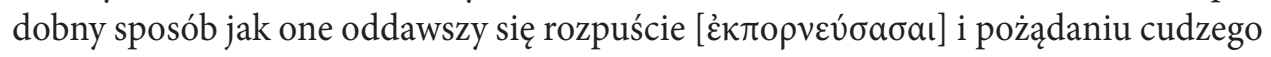

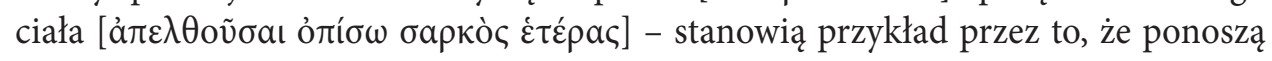
karę wiecznego ognia" $(1,7)$. Zdaniem Gagnona dwa wspomniane przez autora listu występki („rozpusta” i „pożądanie cudzego ciała”) tworzą hendiadys: grzeszne miasta „oddały się rozpuście poprzez pożądanie cudzego ciała”29. O ile wzmianka o rozpuście może być wieloznaczna, o tyle "pożądanie cudzego ciała” w nawiązaniu do historii Sodomy wskazuje na seksualny charakter czynów, których mieszkańcy Sodomy chcieli się dopuścić w stosunku do Bożych wysłańców.

28 Zob. Gagnon, „OT and Homosexuality”, 372-373. Na poparcie swej tezy Gagnon przytacza szereg dodatkowych argumentów. Zob. Gagnon, The Bible, 80-85; Gagnon, „OT and Homosexuality”, 373. Więcej na temat Kpł 18 i 20 w kontekście homoseksualności zob. Strzałkowska, „Homoseksualizm w prawodawstwie biblijnego Izraela", 137-162. 
W podobnym tonie (być może pod wpływem Listu św. Judy) wypowiada się również autor Drugiego Listu św. Piotra. Nawiązuje on do losu grzesznych miast, zapowiadając to, co czeka bezbożnych: „także miasta Sodomę i Gomorę, obróciwszy w popiól, skazał na zagładę, dając przykład tego, co spotka bezbożnych". Nieco dalej precyzuje on, w czym dokładnie wyraża się owa bezbożność: „wie Pan, jak pobożnych wybawiać z doświadczenia, niesprawiedliwych zaś jak zachowywać na ukaranie w dzień sądu, przede wszystkim zaś tych, którzy idą za głosem ciała w nieczystej

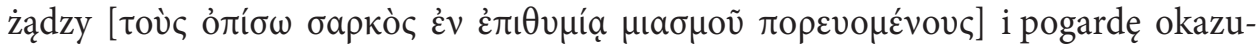
ją Władzy: zuchwalcy, zarozumialcy, którzy nie wahają się przed wypowiadaniem bluźnierstw przeciwko 'Chwałom”' (2,6-10). Jak widać tu również zostaje wyraźnie podkreślony przede wszystkim seksualny (a nie społeczny!) wymiar grzechu, który stanowi podstawę porównania do Sodomy ${ }^{30}$.

Ten sam aspekt zostaje również uwypuklony w literaturze międzytestamentalnej. Reinterpretując opowiadanie o Sodomie, redaktor Księgi Jubileuszów przywołuje motyw rozwiązłości cielesność i nieczystości:

W owym miesiącu Pan wykonał sąd nad Sodomą, Gomorą, Zeboim i nad całym regionem Jordanu. Spalił ich za pomocą ognia i siarki i unicestwił ich po dziś dzież tak jak mówił: Oto Ja dałem ci poznać wszystkie ich uczynki, a oni byli okrutnymi i wielkimi grzesznikami, znieważyli siebie samych rozwiązłością cielesną i tym sprowadzali nieczystość na ziemię. W ten sposób Pan będzie dokonywał sądu, takiego jak sąd nad Sodomą, nad miejscami, gdzie dokonuje się takiej nieczystości jak w Sodomie (Jub 16,5-6).

Jednoznacznie seksualny wymiar występków mieszkańców Sodomy wskazuje również Jub 20,5: „[Abraham] Opowiedział im o wyroku, jaki spadł na olbrzymów, i o wyrokach dla sodomitów, tak jak to zostali osądzeni za ich złe czyny. Umarli z powodu cudzołóstwa, nieczystości oraz zepsucia, jakie panowało wśród nich".

Ponadto o grzechach dotyczących sfery seksualnej w nawiązaniu do Sodomy i Gomory wspominają Testament Lewiego („wasze związki w bezbożności dorównają Sodomie i Gomorze” - TestLew 14,6) oraz Testament Beniamina („dopuścicie się bowiem rozwiązłości na wzór Sodomy" - TestBen 9,1). Testament Neftalego wspomina o naruszeniu porządku naturalnego: „Wy zaś, dzieci moje, nie postępujcie w ten sposób. Pana, Stwórcę wszystkiego, rozpoznawajcie na firmamencie nieba, na ziemi i na morzu, i we wszystkich wielkich dziełach Pańskich, abyście nie stali się jak Sodoma odmieniająca naturalny porządek" (TestNef 3,4$)$.

Motyw naruszenia porządku naturalnego w odniesieniu do występku mieszkańców Sodomy wybrzmiewa bardzo wyraźnie w pismach Filona z Aleksandrii. W swoim dziele De Abrahamo, wspominając Sodomitów, pisze o konsekwencjach braku powściągliwości i umiarkowania oraz nadmiernego dobrobytu:

Zob. Muszytowska, „Kwestia homoseksualizmu”, 307-322. 


\section{KRZYSZTOF NAPORA}

Mężczyźni, nie mogąc znieść spokojnie obfitości tych rzeczy, stają się niespokojni jak bydło i uparci, i odrzucają prawa natury, oddając się z wielką i nieumiarkowaną pobłażliwością obżarstwu, pijaństwu i bezprawnym związkom; Nie tylko bowiem szaleli za kobietami i bezcześcili łoże małżeńskie innych, ale i ci, którzy byli mężczyznami, pożądali jedni drugich, czyniąc rzeczy nieprzyzwoite, nie zważając na wspólną naturę i nie szanując jej $(\text { Abr. 1,135) })^{31}$.

Z kolei Józef Flawiusz w Dawnych dziejach Izraela na pierwszy plan wysuwa motyw pogwałcenia prawa gościnności, a także wrogości oraz zamknięcia w stosunku do obcych, spowodowane nadmiernym bogactwem:

Sodomici, rozzuchwaleni wspaniałością swych bogactw, poczęli wrogo odnosić się do ludzi i do tego stopnia wyzbyli się pobożności, że zapomnieli zgoła o doznanych od Boga dobrodziejstwach i nie chcieli udzielać gościny przybyszom, a sami również nie nawiązywali stosunków z innymi plemionami. Rozgniewany takim postępowaniem Bóg postanowił ukarać ich za ich butę i zniszczyć miasto wraz z okolicą tak doszczętnie, by już nigdy ziemia nie wydała żadnej rośliny, żadnego owocu... (Ant 1,194-195).

Jednakże również w jego interpretacji opowiadania o Sodomie motywy gwałtu na „urodziwych młodzieńcach” oraz niezdolność do „przezwyciężenia żądzy” występują jako istotne elementy charakterystyki mieszkańców Sodomy i ich występków.

Aniołowie zaś przybyli do miasta Sodomitów i Lot zaprosił ich w gościnę. Był bowiem zawsze bardzo gościnny i we wszystkim naśladował cnoty Abrama. Gdy Sodomici ujrzeli, jak niezwykle urodziwi młodzieńcy zatrzymali się u Lota, chcieli zadać im gwałt. Lot wzywał ich do opamiętania, by nie targali się na cześć tych przybyszów i uszanowali ich, jako że są u niego w gościnie. Powiedział nawet, że jeśli nie mogą przezwyciężyć żądzy, wyprowadzi do nich swe własne córki (Ant 1,200-201).

Podsumowując tę część naszego opracowania, możemy stwierdzić za Innocentym Himbazą ${ }^{32}$, że recepcja opowieści o Sodomie i Gomorze w Biblii Hebrajskiej nie podkreśla jakiegoś szczególnego grzechu, ale wskazuje na szereg występków, które wspólnie tworzą obraz miasta grzesznego par excellence. W literaturze późniejszej (od II w. przed Chr.) grzechy mieszkańców Sodomy przedstawiane są przede wszystkim jako występki natury seksualnej, również takie, które naruszają naturalny porządek świata uczynionego przez Stwórcę.

\footnotetext{
31 Szerzej na temat interpretacji grzechu Sodomy w pismach Filona z Aleksandrii i jego wpływie na egzegezę zob. Ahern, „Sin of Sodom”, 214-217.

32 Himbaza - Schenker - Edart, Question of Homosexuality, 12-13.
} 


\section{Zakończenie}

Współczesne zainteresowanie opowiadaniem o występkach mieszkańców Sodomy wydaje się być wpisane w kontekst aktualnego zamieszania na polu antropologii, toczących się dyskusji i sporów o charakterze religijnym, politycznym i światopoglądowym. Gdybyśmy chcieli w tym kontekście dołączyć do toczącej się dyskusji głos teologa-biblisty, to kusząc się o pewną syntezę tego, co zostało wyżej powiedziane, należałoby wskazać kilka istotnych punktów:

a. Wydaje się, że w opowiadaniu o zniszczeniu Sodomy, homoseksualizm nie jest głównym motywem biblijnego opowiadania. Akty homoseksualne, do których dążą bohaterowie tych opowiadań, nie są również jedynymi występkami mieszkańców grzesznego miasta.

b. Warto jednak zwrócić uwagę, że portretując nieprawych mieszkańców grzesznego miasta, redaktor biblijny posługuje się zarówno motywem relacji o charakterze seksualnym, jak również specyficznie motywem relacji homoseksualnej, na które wydaje się wskazywać użyty w tym osobliwym kontekście hebrajski czasownik ידע. Obok takich występków, jak: gwałt, przemoc, agresja, pogwałcenie prawa gościnności, akty homoseksualne (nawet jeśli wprost niezrealizowane, a tylko zamierzone), stają się istotnym elementem obrazu moralnej kondycji miasta i jego mieszkańców.

c. Należy również zwrócić uwagę na ocenę aktów homoseksualnych. W Rdz 19 jest ona jednoznacznie negatywna. Potępienie tych praktyk wydaje się dodatkowo podkreślone przez fakt, że deklarowany zamiar popełnienia aktu homoseksualnego nie zostaje zrealizowany. Wers Rdz 19,11 informuje, że jego potencjalni sprawcy zostają dotknięci ślepotą, zanim dopuszczą się tego czynu. Jednoznacznie negatywna ocena wynika jasno z zakończenia opowiadania: konsekwencją występku jest całkowite zniszczenie miasta.

d. Nie bez znaczenia wydaje się również fakt, że bohaterowie opowiadań wyrażają negatywną ocenę zachowań o charakterze homoseksualnym. Próbując odwieść mieszkańców Sodomy od ich zamiarów, Lot prosi, „by nie dopuszczali się tego występku” (אל־נא אחי תרעו - dosł. „proszę, bracia, nie postępujcie tak źle/niegodziwie"). Co może również do pewnego stopnia ranić naszą współczesną wrażliwość, zachowanie gospodarza wydaje się wskazywać na pewną gradację zła: Lot uznaje, że ewentualny gwałt dokonany na jego córkach stanowi mniejsze zło niż zamierzone akty o charakterze homoseksualnym.

e. Wspomniany wcześniej współczesny kontekst zainteresowania opowiadaniem o zniszczeniu Sodomy każe również zwrócić szczególną uwagę, na proces recepcji i interpretacji tekstu biblijnego. O dynamizmie tego procesu świadczy nie tylko odnotowana w literaturze starożytnej ewolucja poglądów na temat istoty występku mieszkańców Sodomy, lecz również współczesne próby odczytania na nowo tego opowiadania - próby, które niejednokrotnie wydają się raczej wy- 
chodzić naprzeciw doraźnemu zapotrzebowaniu części dzisiejszych czytelników

Biblii, niż szukać prawdy „dla naszego zbawienia”.

Czy opowiadanie o zniszczeniu Sodomy stanowi podstawowy tekst zawierającym kompletną naukę biblijną o relacjach homoseksualnych? Myślę, że nie. Tekst ten implicite odwołuje się zarówno do antropologii zawartej w Rdz 2, jak i prawodawstwa zapisanego w Kodeksie Świętości. Być może nawiązuje również do tradycji deuteronomistycznej zapisanej na kartach Księgi Sędziów. Bez wątpienia stanowić powinien istotny $\mathrm{i}-\mathrm{w}$ moim odczuciu - jednoznaczny punkt odniesienia również we współczesnych dyskusjach na temat Bożego zamysłu wobec mężczyzny i kobiety, człowieka stworzonego na Boży obraz i według Bożego podobieństwa (Rdz 1,26).

\section{Bibliografia}

Ahern, E., „The Sin of Sodom in Late Antiquity”, Journal of the History of Sexuality 27/2 (2018) 209-233.

Alter, R., „Sodom as Nexus: The Web of Design in Biblical Narrative”, The Book and the Text. The Bible and Literary Theory (red. R.M. Schwartz) (Oxford, UK: Blackwell 1990) 146-160.

Bailey, D.S., Homosexuality and the Western Christian Tradition (London: Longmans, Green 1955).

Bird, P., „The Bible in Christian Ethical Deliberation Concerning Homosexuality: Old Testament Contributions", Homosexuality, Science, and the "Plain Sense" of Scripture (red. D.L. Balch) (Grand Rapids, MI: Eerdmans 2000) 142-176.

Boyarin, D., „Are There any Jews in 'The History of Sexuality'?”, Journal of the History of Sexuality 5/3 (1995) 333-355.

Edwards, G.R., Gay/Lesbian Liberation. A Biblical Perspective (New York: Pilgrim Press 1984). Fields, W.W., „The Motif 'Night as Danger' Associated with Three Biblical Destruction Narratives", "Sha 'arei Talmon". Studies in the Bible, Qumran, and the Ancient Near East Presented to Shemaryahu Talmon (M. Fishbane - E. Tov) (Winona Lake, IN: Eisenbrauns 1992) 17-32.

Fields, W.W., Sodom and Gomorrah. History and Motif in Biblical Narrative (Journal for the Study of the Old Testament Supplement Series 231; Sheffield: Sheffield Academic Press 1997).

Gagnon, R.A.J., The Bible and Homosexual Practice. Texts and Hermeneutics (Nashville, TN: Abingdon 2001).

Gagnon, R.A.J., „The Old Testament and Homosexuality: A Critical Review of the Case Made by Phyllis Bird”, Zeitschrift für die Alttestamentliche Wissenschaft 117 (2005) 367-394.

Gnuse, R.K., „Seven Gay Texts: Biblical Passages Used to Condemn Homosexuality”, Biblical Theology Bulletin 45/2 (2015) 68-87.

Grisanti, M.A., „Homosexuality - An Abomination or Purely Irrelevant? Evaluating LGBT Claims in Light of the Old Testament (Gen. 18-19; Lev. 18:22; 20:13)", The Master's Seminary Journal 28/2 (2017) 115-133. 
Hershon, P.I., Tzeénah ureénah: "Go ye and see”. A rabbinical commentary on Genesis. Translated from the Judaeo-Polish, with Notes and Indices (London: Hodder \& Stoughton 1885).

Himbaza, I. - Schenker, A. - Edart, J.-B., The Bible on the Question of Homosexuality (Washington, D.C.: Catholic University of America Press 2012).

Józef Flawiusz, Dawne dzieje Izraela, wyd. 3 (tł. Z. Kubiak - J. Radożycki) (Warszawa: Rytm 1993) I-II.

Lemański, J., Księga Rodzaju. Rozdziały 11,27-36,43. Wstęp, przekład z oryginału, komentarz (Nowy Komentarz Biblijny. Stary Testament 1/2; Częstochowa: Edycja Świętego Pawła 2014).

Loader, J.A., A Tale of Two Cities. Sodom and Gomorrah in the Old Testament, Early Jewish and Early Christian Traditions (Contributions to Biblical Exegesis and Theology 1; Kampen: Kok 1990).

Lyons, W.J., Canon and Exegesis. Canonical Praxis and the Sodom Narrative (Journal for the Study of the Old Testament Supplement Series 352; London - New York: Sheffield Academic Press 2002).

Matthews, V.H., „Hospitality and Hostility in Genesis 19 and Judges 19”, Biblical Theology Bulletin 22 (1992) 3-11.

McNeill, J.J., The Church and the Homosexual (Kansas City, MO: Sheed Andrews \& McMeel 1976).

Morschauser, S., „'Hospitality', Hostiles and Hostages: On the Legal Background to Genesis 19.1-9", Journal for the Study of the Old Testament 27 (2003) 461-485.

Muszytowska, D., „Kwestia homoseksualizmu w Listach Powszechnych i Apokalipsie św. Jana”, Verbum Vitae 39/1 (2021) 307-322.

Nissinen, M., Homoeroticism in the Biblical World. A Historical Perspective (Minneapolis, MN: Fortress 1998).

Skinner, J., Genesis (International Critical Commentary 1; Edinburgh: Clark 1910).

Strzałkowska, B., „Homoseksualizm w prawodawstwie biblijnego Izraela”, Verbum Vitae 39/1 (2021) 137-162.

Toensing, H.J., „Women of Sodom and Gomorrah: Collateral Damage in the War against Homosexuality?", Journal of Feminist Studies in Religion 21/2 (2005) 61-74.

Wenham, G.J., Genesis 16-50 (The Word Biblical Commentary 2; Dallas, TX: Word Books 1994).

Wenham, G.J., „The Old Testament Attitude to Homosexuality”, Expository Times 102 (1991) 359-363.

Westermann, C., Genesis 12-36 (A Continental Commentary; Minneapolis, MN: Fortress 1995).

Wright, D.F., „Homosexuality: The Relevance of the Bible”, The Evangelical Quarterly 61/4 (1989) 291-300. 
